\title{
MARINES AND MARINERS IN THE ROMAN IMPERIAL FLEETS
}

\author{
JASPER OORThuijs
}

\begin{abstract}
Since Chester Starr's 1941 book The Roman Imperial Navy it has become generally accepted knowledge that "the crew of each warship, regardless of its size, formed one centuria under its centurio (classicus) in the manner of a legionary centuria." Boldly stating his case, Starr solved one of the most problematic peculiarities in the epigraphic habit of Roman naval troops in one great swoop. The problem referred to is the following: in roughly two thirds of the exstant inscriptions milites of the imperial fleets stated that they belonged to some kind of warship, while the other third indicated that they belonged to a centuria. A small number indicated neither and a very few referred to both ship and centuria. Starr's statement was never challenged despite the problems that clearly exist with this theory. In what follows some of those problems will be addressed.
\end{abstract}

First of all, the consequence of Starr's theory is that we have to accept the idea that centuriones classici commanded a great range of troops: ship's crews ranged in size from some 50 men for a liburna up to 400 in quinqueremes. ${ }^{2}$ There are however no indications of different grades of centurio in the fleets. Moreover, because Starr squeezes a naval and army hierarchy into one, the trierarchs and navarchs, whether captains or squadron commanders, have to be forced in somewhere. Starr himself never seems to have found a satisfying solution for that problem and its practical results. While the statement quoted above would put the centurio in overall command, elsewhere he suggested that the centurio ranked below the naval officers. Did they hold command depending on the task at hand as he stated? ${ }^{3}$

\footnotetext{
${ }^{1}$ Ch.G. Starr, The Roman Imperial Navy (Chicago 1963, 3rd ed.), 57.

${ }^{2}$ Polybius I.26.7; Pliny, Naturalis Historia XXXII.2; J.S. Morrison, Greek and Roman Oared Warships (Oxford 1996), 317.

${ }^{3}$ Starr, op. cit. (n. 1), 42-43: "The naval centurions at all times ranked beneath the navarchs and trierarchs", and p. 61: "It would seem more logical that the centurion,
} 
The epigraphic evidence for Starr's theory can hardly be called extensive. Explicit support for his theory can only be found in a single inscription in which a gubernator referred to a centuria. ${ }^{4}$ But it requires on the other hand that at least three inscriptions where both ship and centuria are named be disposed of as pedantry. ${ }^{5}$ For those cases and for the inscriptions where troops refer to a centuria followed by a ships's name or where former centuriones refer to a ship another solution will be proposed further down. In order to provide that, one must first understand the internal structure of the fleets.

The peculiar hierarchy at the lowest levels of Rome's classes has often led to claims that the rowers, sailors and marines were one amorphous mass: they would all have received military training and basically have been interchangable. ${ }^{6}$ It is true that the epigraphical testimonies at first sight seem to leave little room for another conclusion. There is but one inscription in which a sailor is actually described as nauta. ${ }^{7}$ In all other cases the rank and file of naval forces is described as classici, gregales and of course as milites. Manipularii (or manipulares) are usually counted among these as well. ${ }^{8}$

By comparison to the extensive specialization found in the legions and auxilia, it is illogical to think that in the classes there would not even have been a differentiation between those looking after the mobility of the ship and those doing the fighting. This is all the more surprising, because it flies in the face of a long-established naval tradition, not just in the Roman, but in the Greek and Hellenistic world as well.

while at sea, should command only the small group of marines and have no other authority, and that during service of the entire crew on land the naval ranks would be generally disregarded and the centurion become chief."

${ }^{4}$ CIL X 3385: D(is) M(anibus) | M(arci) Antoni Apol[loni(?)] | gubernato[ris] | centur(ia) $\operatorname{Ar}[\mathrm{ri}($ ?). Might it be presumed that centur(ia) is written in a much fuller version than the usual sign for centuria?

${ }^{5}$ Starr, op. cit. (n. 1), 63 n. 29 mentions CIL VI 3165 and IX 42. The latter may be a misreading (CIL IX p. 652). Other cases have since been published in AE 1939, 227 and AE 1978, 311.

${ }^{6}$ M. Reddé, Mare Nostrum (Rome 1986), 523. Starr suggests military training for all (op. cit. [n. 1], 58), but finds no evidence for the group itself and emphasises his centuria = ship's crew theory. G. Webster, Roman Imperial Army (Oklahoma 1998, 3rd ed.), 166 follows Starr.

AE 1900, 185.

${ }^{8}$ Starr, op. cit. (n. 1), 59. Kienast disagreed on the basis of AE 1896, 21 alone, but deplored the lack of further evidence to support his contention that manipulares were the decksoldiers of the Roman fleets (Untersuchungen zu den Kriegsflotten der Römischen Kaiserzeit [Bonn 1966], 23 and n. 61). 
Rowers and sailors on the one hand and marines, the boarding party, on the other, usually came from different property and status classes. ${ }^{9}$ Is it really necessary to expect Augustus to have changed that tradition radically?

At the very end of the Republican era Octavian's fleets fought Marc Antony with (probably specialized) legionaries embarked as a boarding party. These marines were certainly not part of the crew of these ships. ${ }^{10}$ Did Augustus change the situation? He was confronted with three possibilities:

${ }^{9}$ L. Casson, Ships and Seamanship in the Ancient World (Baltimore 1995, 2nd, revised ed.), 304-309;

${ }_{10}$ Polybius 6.19; Livy XXIV.11; J.H. Thiel, A History of Roman Sea-Power before the Second Punic War (Amsterdam 1954), 196; J.H. Thiel, Studies on the History of Roman SeaPower in Republican Times (Amsterdam 1946), 12, 59, 189. Thiel theorized that some 40 marines belonged to the permanent establishment of the navies (Studies, 196), but based that solely on Polybius VI.19, which says that the lowest property class did naval service. Perhaps it was a reaction to bad experiences suffered or simply through longtime naval service, at the end of the civil wars, specialized marine legions begin to appear. Lucius Trebius of CIL V 938, miles classicus for 17 years in Augustus' service may have been one of these: L. Keppie, Colonisation and Veteran Settlement, 47-14 BC (Rome 1983), 31. The same goes for Gabienus in Pliny, Naturalis Historia VII.178. Judging by the extant evidence several legiones classicae must have existed as early as 43 BC. The colonies of Suessa and possibly Teanum had Classica in their titulature, indicating the settlement of legions with the same epithet (Appian, Bella Civilia IV.3; CIL X 4832; Keppie, Colonisation 18. Keppie points out that 'Cl' in the case of Teanum could be emended to Classica or Claudia, pp. 139-141. The latter is the emendation of the CIL: CIL X 4781, 4799. Pliny does not give Classica as part of the titulature of either town however: Naturalis Historia III.63. Dating of these colonies: Keppie, Colonisation 141, 143). No number is known for the legions that supposedly colonized these towns. Legio VIII colonized Teanum, but no naval service is known (Keppie, Colonisation 140). However, other legiones classicae are known by number. Caius Edusius was centurio of Legio XXXXI and centurio classicus, while Caius Cannutius and Aticius belonged to Legio XXX Classica (CIL XI 4654 = ILS 2231; Keppie, Colonization 31 and appendix n. 94. Aticius: CIL X $18=$ ILS $2232=$ Keppie, Colonisation appendix n. 76. Cannutius: AE 1997, 1416. For Legio XXX Classica, see E. Ritterling, Legio in PWRE XII, 1821. According to Ritterling, Legio XXX Classica is probably the same Legio XXX that settled in Beneventum). Antony too had at least one Legio Classica, evidenced by his legionary series of coins (Ritterling, 'Legio', 1768. Many other coins in this series carry galleys reminding of naval service). Finally, by far the most famous and only surviving imperial legion with naval service in its heritage is Legio X Fretensis. Both its epithet Fretensis (Fretum Siculum, the strait of Messina) and its emblems, the galley and dolphin, hark back to the days when this legion served in the war against Sextus Pompeius. See Ritterling, 'Legio', 1671, updated by E. Dabrowa, 'Legio X Fretensis' in Y. Le Bohec, Les légions de Rome sous le Haut-Empire (Paris 2000), 317-325 without any new information on the origin of this legion. See also D. Barag, 'Brick Stamp-Impressions of Legio X Frentensis', BJ 167 (1967), 244-267. 
- Augustus did not change the internal structure of the fleets and planned to use legionary or auxiliary troops as marines when needed;

- Augustus incorporated specialized marines into the standing fleets as a separate, possibly higher status category of personnel;

- Augustus ensured that all rowers and sailors were also militarily trained and could instantly replace one another at whatever task they were supposed to perform.

The proposition here is that the situation during Augustus' reign is best described by the first option: the legionary troops were withdrawn from the fleet and included in the overall reorganization of legions into a new legionary establisment. This is confirmed by the make-up of the fleet in Forum Iulii. These squadrons, Tacitus states, were installed at Forum Iulii valido cum remige, with strong crews. ${ }^{11}$ Despite the usual reservations about Tacitus' use of technical terminology, what needs to be understood here is that Tacitus is indeed describing the rowers of the fleet, not marines, nor the crews as a whole. ${ }^{12}$ This statement may be corroborated by a small number of epitaphs from the area around modern Nice. They attest to an otherwise unknown unit, the Cohors Nautarum or Nauticarum and date to the early Julio-Claudian period. They are the following inscriptions:

CIL V $7884=$ IANice $00048=$ Holder $^{13}$ n. 1904

Apolonio

Dionysio

mil(iti) co[h(ortis)] na(uticorum)

tubic(ini) h(eres) e(x) t(estamento)

11 Tacitus, Annals IV.5. How this came to be is unclear, for it is explicitly noted in the Actium campaign histories that Antony's crews were understrength through hunger, disease and desertions (Dio L.12.7, 14.4, 15.4; Orosius VI.19; Plutarch, Marcus Antonius 68). For a discussion, see for instance W. Murray, 'Reconsidering the Battle of Actium-Again', in V. Gorman and E. Robinson, eds., Oikistes. Studies in Constitutions, Colonies, and Military Power in the Ancient World Offered in Honor of A.J. Graham. Mnemosyne Supplement 234 (Leiden 2002), 341. One may assume that the surviving crews of Antony's fleet were redistributed over a selected number of ships and/or that they were reinforced with rowers and sailors from Octavian's own fleet.

12 Tacitus clearly uses remiges (and the related remigium) in those situations where he wants to indicate those who are responsible for moving the ship or the crew in it. Cf.: (propulsion) Annals II.6; III.1; XII.56; XIV.4; XVI.2; Agricola 10.5; Germania XLIV.2; Histories II.35, V.23 (crew) XIV.5; XIV.39; Histories III.76; V.21. For Tacitus' value for hierarchy, see M. Ducos, 'La hiérarchie militaire dans les sources littéraires', in Y. Le Bohec, ed., La hiérarchie de l'armée romaine sous le haut-empire (Paris 1995), 47-52.

${ }_{13}$ P.A. Holder, The Auxilia from Augustus to Trajan. BAR International Series 70 (Oxford 1980). 
CIL V 7887 = IANice $00048=$ Holder n. 1902

Ti(berio) Iulio Ti(beri) Iulii F[i] $\mathrm{rmi}^{14}$

duplic(arii) $\operatorname{coh}$ (ortis) naut(icorum)

lib(erto) Fausto patronus

CIL V 7888 (p 931) = Holder n. 1903

Ti(berio) Iulio Vell/aconis fi[(io)]

Glutaco

miles coh(ortis) naut(icorum)

7(centuria) Hicuris

hered(es) ex tes(tamento) h(ic) s(itus) e(st)

CIL V $7892=$ IANice $00048=$ Holder n. 1901

L(ucio) Nonio Quadrato co[h(ortis)] naut(icorum)

[7 (centuria)] Mum(mi) Ius(ti?) Q(uintus) Manilius et Ca[l]

ventius Rufus d(e) s(uo)

AE 1964, $249=$ InAntNice-Cimiez $048=$ HD003625 = Holder n. 1905

Mario Sace(?) f(ilius)

gen(te) Dareus coh(ortis)

nautic(orum) 7(centuria) Pacati h(eres) e(x) t(estamento)

h(ic) s(itus) e(st)

These tombstones, mostly lost now, were dated to the Neronian era on the basis of a derived dating of a tombstone of another unit in the area. ${ }^{15}$

The location of one of these gravestones, the unit's epithet and the eastern name of Apolonius Dionysius surely indicate a relation to the sailors of the squadron at Forum Iulii. ${ }^{16}$ In fact, if that soldier's tombstone belongs to the last decades before the birth of Christ, it is not inconceivable that Dionysius was a veteran of Antony's fleet. ${ }^{17}$ But how did this unit come to exist? Due to a lack of sources, it is debatable, but a probable solution is one that has elsewhere been suggested for the Cohors I Classica: when Augustus returned Gallia Narbonensis to

14 Possibly a fictitious filiation. Holder's transcription.

15 Holder, op. cit. (n. 13), 164.

16 Spaul, Cohors 2. BAR International Series 841 (Oxford 2000), 478 n. 3, suggests that the nation of Marius Sace(?), Dareus, might indicate an eastern origin too. He could have been a Phrygian. Alternatively he may have come from the French Var valley.

17 It is perhaps not insignificant that the only tombstone of a man who actually designates himself as 'nauta' is a very early one (AE 1900, 185), Lucius Boionius Zeno serving on the trireme Phryx, was undoubtedly an easterner too. 
the senate's control, he may have partially disarmed it. ${ }^{18}$ Soldiers who had yet time to serve may have been transferred to an infantry unit with, it seems, a normal infantry hierarchy. The tombstone of Tiberius Iulius Glutacus obviously dates to the period after Tiberius'reign, which means that the unit stayed active during the Iulo-Claudian period, but was at some point allowed to die out. There is at least no evidence of its existence in later periods. ${ }^{19}$

Therefore it may be concluded that Augustus had a fleet in Forum Iulii which had no integral marines to serve as boarding parties.

The case of Cohors I Classica, which has always been connected to this early fleet, may reinforce this theory. ${ }^{20}$ The connection to Forum Iulii lies in CIL XIII 923 and AE 1904, 7, both epitaphs of soldiers originating in this city. ${ }^{21}$ There is however no evidence for this unit ever having served in or near Forum Iulii. ${ }^{22}$ Instead, the oldest tombstones come from Eysses, Aquitania. They are the one named before and CIL XIII 924, concerning a soldier who is, judging by his tribus, not from Forum Iulii. ${ }^{23}$

The purpose for which the unit was established is perhaps easier to explain. Many scholars have pointed to a single sentence in Florus

${ }^{18}$ K. Kraft, Zur Rekrutierung der Alen und Kohorten an Rhein und Donau (Bern 1951), 97-98.

19 P.A. Holder, The Roman Army in Britain (London 1982), 119, points to CIL XVI 82, a British diploma which includes...naut in a fragmentary cohors name. The separate ' $n$ ' just before it, however, indicates a more extensive name, emendated by M.G. Jarret, 'Non-Legionary Troops', Britannia 25 (1994), 35-77, esp. 63, to the cohors I Menapiorum Nautarum. See also Spaul, op. cit. (n. 16), 185.

${ }^{20}$ Kraft, op. cit. (n. 18), 97-98; Starr, op. cit. (n. 1), 188.

${ }^{21} \mathrm{AE}$ 1904, 7 = Holder, op. cit. (n. 13), no. 3143: "C(aio) Lucceio L(uci) f(ilio) Ani(ensi) veteranus cohortis I classicae et Camuriae Ter[ti] ae Sertori Sertoris filia genero et filiae" (found in Forum Iulii), a veteran who may have returned to his home; CIL XIII 923 “|(Obitus) Sex(tus) Valerius Sex(ti) | f(ilius) Ani(ensi) Maxsumus(!) For[o] | Iuli mil(es) coh(ortis) I classic(ae) | 7(centuria) Petroni ann(orum) XX[3] | stipendior(um) XX[3] | h(ic) s(itus) est | C(aius) Valerius Adi[utor?] | fratri pientis[simo].”

${ }_{22}$ The Cohortes Classicae served in Aquitania, Germania Inferior and Syria (Spaul, op. cit. [n. 16], 477-478), the garrison of Forum Iulii consisted of a Cohors Ligurum, which had been in the area for a long time ("vetus loci", Tacitus, Histories II.14; see also: G.E.F. Chilver, A Historical Commentary on Tacitus' Histories I and II [Oxford 1979], 179). A Cohors I Ligurum and Hispanorum left many traces of its stay in the area around Nice, see Spaul, op. cit. (n. 16), 269.

23 "Valerius Gal(lus?) | Vol(tinia?) Tutus Lu|co miles coh|ortis I class|icae an(norum) XXII | [d]ie(rum) VIIII h(ic) s(itus) e(st). Kraft, op. cit. (n. 18), 98. 
and Orosius concerning the operations against the Cantabri. ${ }^{24}$ Both authors apparently tell of naval raids executed against the Cantabri. Aquitania would be the logical base for such operations, as is attested by Orosius. Whether the fleet from Forum Iulii had sailed around the entire peninsula to transport the troops, is debatable. However, since there is no evidence at all to help one decide, it is just as likely that the ships were built locally. Warships were not really necessary and in this case simple transports would have done. Is it then not as likely that these units were raised in Southwestern Gaul for service as maines with the fleet that was used against the Hispanic tribes?

The idea that this unit may have provided marines is suggested by an essential difference between the Cohors Nautarum and the Cohors I Classica: while the former probably consisted of peregrines, the latter was recruited from citizens. ${ }^{25}$ Although two of the inscriptions cited for the Cohors Nautarum show that the soldier in question had a full tria nomina, this is not a definitive indication for citizenship. ${ }^{26}$ One other probably does and two other tombstones do not show the tria nomina. No tribus or filiation is given. The soldiers of Cohors I Classica on the other hand are all citizens as is attested to by the filiation and tribus in even the earliest inscriptions. ${ }^{27}$ In view of their higher status, and also combined with the epithet of this unit in contrast to the Cohors Nautarum, it is not unlikely that the troops of Cohors I Classica performed the task of marines, or a boarding party. ${ }^{28}$

${ }^{24}$ Florus II 33.49: "nec ab Oceano quies, cum infesta classe ipsa quoque terga hostium caederentur."; Orosius VI 21.4: "tandem ab Aquitanico sinu per Oceanum incautis hostibus admoveri classem atque exponi copias iubet". Modern literature e.g. Kraft, op. cit. (n. 18), 97; D.B. Saddington, 'The Origin and Character of the Provincial Fleets of the Early Roman Empire', in V.A. Maxfield and M.J. Dobson, Roman Frontier Studies 1989. Proceedings of the XVth International Congress of Roman Frontier Studies (Exeter 1991), 397; Reddé, op. cit. (n. 6), 350-351.

${ }_{25}$ Apart from the difference in name, location and temporal problems, this is the best indication that these two units are separate entities. Contra: Spaul, op. cit. (n. 16), 478.

${ }_{26}$ A. Mócsy, 'Die Namen der Diplomenempfänger', in W. Eck and H. Wolff, eds., Heer und Integrationspolitik. Die römischen Militärdiplome als historische Quelle (Cologne 1986), 462.

${ }^{27}$ For instance: CIL XIII 923: "Sex(tus) Valerius Sex(ti) | f(ilius) Ani(ensi) Maxsumus(!)", XIII 924 "Valerius: Gal(lus?) | Vol(tinia?) Tutus Lu|co" and AE 1904, 7 "C(aio) Lucceio L(uci) f(ilio) Ani(ensi)." See Kraft, op. cit. (n. 18), 95.

${ }^{28}$ Mention must here be made of Kraft's theory (op. cit. [n. 18], 95) that the soldiers of I Classica received their citizenship from Valerius Messala Corvinus, who was in command of early operations in Aquitania. (RE VIII.131-158, esp. 148-153) for which he celebrated a triumph in 27 BC. Despite Augustus' later great reticence in awarding 
The evidence of these early imperial auxiliary units therefore indicates that at the very beginning of his reign, Augustus did not change the Republican naval situation. And knowing the long-standing status difference between the two parts of a ship's complement, it is unlikely that he would have wanted to change it.

The obvious question now is whether this situation ever did change? An overview of the available source material is enlightening. On the question of the internal specialization one fragment of Ulpian's has often been quoted or pulled out of context. It concerns Digests XXXVII.13.1.1, usually quoted as "In classibus omnes remiges et nautae milites sunt." Tempting though it may be to read that this means that all rowers and sailors were militarily trained, that would be wrong. The full paragraph runs as follows:

Item nauarchos et trierarchos classium iure militare posse testari nulla dubitatio est. in classibus omnes remiges et nautae milites sunt. Item vigiles milites sunt et iure militari eos testari posse nulla dubitatio est. ${ }^{29}$

Ulpian's purpose in the chapter is to determine that those who would not be expected as such are soldiers according to military law and therefore entitled to make out their wills accordingly. He states first that for all those who serve in enemy territory (whether normally counted as soldier or not) and die there will have their wills treated as valid under military law. Ulpian then deals with naval personnel, but - and this is why it is vital to quote the whole paragraph - he is clearly implying categories by using in classibus and specifying which groups were involved. He could have lumped everyone together as classici as he did the vigiles. He also does not name the centuriones classici among the officers, for the simple reason that nobody would have any doubts as to their status. Similarly,

citizenship, this cannot be excluded for an operation this early in his reign. On the other hand, Messala had had fleet commands earlier, at Naulochus and Actium (T.R.S. Broughton, The Magistrates of the Roman Republic 2 [1985], 403 and 422) and Forum Iulii possibly became a colonia after the former battle as well (L. Keppie, 'Soldiers and Veterans at the Colony of Forum Iulii (Fréjus)', in Le Bohec, op. cit. [n. 12], 372). The soldiers of I Classica may well already have had their citizenship, either as citizens of Forum Iulii or, finally, as part of one of the legiones Classicae of the Civil Wars.

29 "Likewise, there is no doubt that navarchs and trierarchs of the fleet can make a will according to military law. In the fleets, all the rowers and sailors count as soldiers. Likewise, vigiles are soldiers, and there is no doubt that they can make a will in accordance with military law." 
the Urbanici, another unit with atypical tasks, is missing. Their military hierarchy and status, however, was undeniable. ${ }^{30}$

Vegetius, an admittedly far later and not always trustworthy source, confirms this picture. He is careful to distinguish between the tasks and groups on board ship. ${ }^{31}$ Most importantly he describes the milites as wearing arms and armour in caput 44, having described the tasks of the rowers in the previous chapter. ${ }^{32}$ Does that mean that the armed soldiers depicted on a few naval tombstones are marines? ${ }^{33}$ That is certainly a possibility, which could be strengthened if we could decide whether marines still held higher status and therefore were more likely to be able to pay for such elaborate and expensive memorials. It may well be that these soldiers were on detached duty from their ship (only one inscription refers to a warship, the others to a centurio. One mentions nothing more specific than his fleet) and performed military duties elsewhere. The same goes for the armed soldier Terentianus, serving in the Alexandrine fleet. ${ }^{34}$ The only time he mentions service aboard, he is sick and lying on deck. Was he a marine or a rower? His later transfer to a legion may be related to service as a marine or due to outside influences.

What of epigraphic source material? Can we discern different groups among the hundreds of inscriptions relating to the Roman fleets? As already suggested by the discussion above, there may be a valid reason for the variation in references on tombstones.

An indication may perhaps be found in the unique rank of suboptio. ${ }^{35}$ It is so rare that Von Domaszewski missed it completely in his discussion, as did Dobson in his update. Reddé only mentions the rank, Starr assigns it to a shared command of the marines (together with the optio), while Spaul considers the existence of this rank as extra

\footnotetext{
${ }^{30}$ See H. Freis, Die Cohortes Urbanae (Cologne 1967), 44-45. They do figure elsewhere in texts by Ulpian in the Digests.

${ }^{31}$ E.g.: IV.32; 38; 43-44; 45; 46. 523.

32 By milites we should therefore not understand 'matelots' with Reddé, op. cit. (n. 6),

${ }^{33}$ CIL III $6109=$ InscrAtt $26=$ AE 1999, 1485; CIL III 556a = InscrAtt 10; EE V, 208; CIL III 557 = InscrAtt 11; EE V, 201.

${ }_{34}$ P. Mich. VIII 467-468. Cf. P. Aberdeen 70.

${ }_{35}$ AE 1896, $21=$ AE 1897, $51=$ AE 1922, 135; AE 1961, $257=$ AE 1985, 401; CIL 10, 3496; CIL 10, 3497; CIL 11, 67; CIL 11, 349 = ILS 2860; CIL 11, $3531=$ ILS 2859. AE 1961, 257 is a plain list of names grouped by rank.
} 
evidence that the centurio must have commanded more than just the marines aboard. ${ }^{36}$

All seven inscriptions with this rank, mentioning many more than seven suboptiones in total, were set up by men of the Classes Praetoriae, judging by the fleets mentioned and/or the places were they were found. In those cases where the ship is mentioned, it concerns triremes in most cases and in one case a quadrireme. From the inscriptions, it cannot be discerned what salary level was connected with this rank. If the Q. Arruntius Valens who occurs in two separate sources is the same person, promotion to optio was possible and a suboptio therefore was not a duplicarius, but more likely a sesquiplicarius or even an immunis. ${ }^{37}$

On a ship with 200 or more crewmen and a centurio in command, it would be understandable if this officer had more than one assistant. However, the larger part of those crewmen were rowers under control of the specialist naval hierarchy. The centurio would then only need to command the few dozen marines on board. It is unlikely that he needed more assistants to fulfil that task on the relatively small area of the ship's deck, no more than a normal centurio in battle needed assistance.

Two possible solutions present themselves. The suboptio may have been an extra assistant to the centurio on land, if he indeed commanded the complete crew in that case. The alternative is that the centurio, optio and suboptio commanded the marines only and held independent command over a group of marines aboard several ships. If so, this would be a continuance of the situation in the fleets of the Late Republic where centuriae of the legions detached for fleet services necessarily must have been divided across several ships.

The contract AE 1896, $21^{38}$ seems to support this last option. In it, seven classiarii of the Classis Misenensis are mentioned. Caius Fabullius

${ }^{36}$ Reddé, op. cit. (n. 6), 538; Starr, op. cit. (n. 1), 60; Spaul, op. cit. (n. 16), 54.

${ }^{37}$ CIL 10, 3464a; CIL 10, 3469; Starr, op. cit. (n. 1), 61. That Valens seemingly changed ships for his promotion may be significant.

38 "C(aius) Fabullius Macer optio classis praetor(iae) Misenatium III(triere) | Tigride emit puerum natione Transfluminianum | nomine Abban quem Eutychen sive quo alio nomine | vocatur annorum circiter septem pretio denariorum | ducentorum et capitulario portitorio de Q(uinto) Iulio | Prisco milite classis eiusdem et triere eadem eum pue|rum sanum esse ex edicto et si quis eum puerum | partemve quam eius evicerit simplam pecuniam | sine denuntiatione recte dare stipulatus est Fabul|lius Macer spopondit Q(uintus) Iulius Priscus id fide sua | et auctoritate esse iussit C(aius) Iulius Antiochus mani|pularius III(triere) Virtute | eosque denarios ducentos qui $\mathrm{s}$ (upra) s(cripti) sunt probos recte | numeratos accepisse et habere dixit Q (uintus) Iulius Priscus | venditor a $\mathrm{C}($ aio) Fabullio Macro emptore et tradedisse(!) ei | mancipium 
Macer, the buyer and an optio, and Quintus Iulius Priscus, a miles and the seller, belong to the triere Tigris. Gaius Iulius Antiochus, manipularius, and Gaius Iulius Demetrius, a bucinator, served on the triere Virtus, while the suboptiones Gaius Iulius Titianus and Gaius Arruntius Valens served on the Liber Pater and the Salus respectively. Finally, the centurio Caius Iulius Isidorus was on the triere Providentia.

What is immediately striking is that in this case the seven men involved serve on no less than five different ships. Interestingly, neither the optio, nor the suboptiones or the centurio come from the same ship. Now of course it is perfectly possible that Macer and Priscus asked crewmembers of other ships to testify to the sale, but it is at least a noteworthy coincidence that they could not find their superiors of their own ship willing to help out.

Optiones and centuriones of the fleets rarely figure together in inscriptions. There is in fact just one other inscription, where the centurio and optio again do not belong to the same ship. ${ }^{39}$ Two inscriptions is not much to go on, but they at least seem to support the theory that the centurio may have been in command of a group of soldiers that was divided over several ships when serving at sea. To keep control over these smaller groups, perhaps 20-30 troops out of an assumed 80 men centuria, the centurio would have needed more than just his single optio. This is where the suboptio came in.

In this way a completely different internal hierarchy of the fleets can be reconstructed which is in fact split in two. There was one naval

\footnotetext{
$\mathrm{s}$ (upra) s(criptum) Eutychen bonis condicionibus | actum Seleuciae Pieriae in castris in hibernis vexilla| tionis clas(sis) pr(aetoriae) Misenatium VIIII Kal(endas) Iunias Q(uinto) Servilio | Pudente et A(ulo) Fufidio Pollione co(n)s(ulibus) | Q(uintus) Iulius Priscus mil(es) III(triere) Tigride vend $<\mathrm{i}=\mathrm{E}>$ di C(aio) Fabullio Macro optioni | III/triere) eadem puerum meum Abbam quem et Eutychen et re/cepi pretium denarios ducentos ita ut s(upra) s(criptum) est | C(aius) Iulius Titianus(?) suboptio III(triere) Libero Patre et ipse rogatus pro $\mathrm{G}($ aio!) Iulio Anti $\{\mathrm{h}\}$ oc(h)o manipulario III(triere) Virtute qui negavit se lit(t)eras | scire eum spondere et fide suam et auctoritate esse Abbam cuen(!) ed(!) Eutychen puerum ed(!) pretium eius denarios ducentos | ita ut s(upra) $\{\mathrm{S}\}$ scr[i]ptum est | C(aius) Arruntius Valens suboptio III(triere) Salute signavi | G(aius!) Iulius Isidorus |(centurio) III(triere) Providentia signavi | G(aius!) Iulius Demetrius bucinator pri[n]cipalis III(triere) Virtute signavi.

${ }_{39}$ I only know of one other example where they are specifically mentioned: CIL 10, 3381: "D(is) M(anibus) | C(aius) Hammonius | Fortis |(centurio) III(triere) Spe na|tione Aeg(yptus?) vix(it) | annis XXXVIII in his | mil(itavit) an(nis) XVIII C(aius) $\mathrm{Pe} /$ tronius Clemens opt(io?) | III(triere) Diana amico bene me|renti fecit. Clemens is in this case specifically mentioned as a friend, which may explain why the heir is not a crewmember.
} 
hierarchy for the rowers and sailors, commanded by the trierarchs. Next to that existed a separate hierarchy, consisting of marines in a normal military hierarchy. When needed, these centuries would be divided over the ships in the squadron. This explains why some milites refer to both the ship and centuria in which they served.

When did this situation change? Literary sources combined with the evidence from a few early diplomata indicates such a change by the emperor Claudius. Tacitus' description of the attempted murder of Agrippina Minor mentions a trierarch and a centurio classicus at the same time. ${ }^{40}$ $58 \mathrm{AD}$ is then the terminus ante quem. Diploma CIL XVI.1 (52 AD) was issued trierarchis et remigibus of the fleet in Misenum. ${ }^{41}$ Chronologically, a number of diplomas follow that mention veterani, which is inconclusive. The change-over may be deduced from RMD IV.205, which was also formally issued to the rowers and trierarchs, but was actually granted to a centurio. If this was the first generation of marines in the organisation of the classes to qualify for honesta missio, then they would have started to serve in 44/45 AD, which fits precisely with Claudius army reforms. ${ }^{42}$ The error in the diploma may be due to the newness of the situation. By $86 \mathrm{AD}$, the diploma copyists had adapted to the new situation for in this year one finds find the first diploma to be issued classicis. $^{43}$

The conclusion that follows, suggests itself: the milites that referred to a centuria were part of the marines of the fleets. When they referred to a ship as well, they indicated what ship they were (temporarily) attached to. That makes even more sense if one remembers that the Italic fleets especially, were not assigned to a single province. When a ship, or ships, were stationed somewhere or out on an expedition, the larger entity would have been the ships the troops served on.

\footnotetext{
40 Tacitus, Annals XIV.8: "trierarcho Herculeio et Obarito centurione classiario."

${ }^{41}$ Cf. CIL XVI.24 (Sept. 8, AD 79), Egypt and RMD IV.205 (Apr. 5th, AD 71), Ravenna.

${ }^{42}$ C. Thomas, 'Claudius and the Roman Army Reforms', Historia LIII/4 (2004), 451.

${ }^{43}$ CIL XVI.32.
} 